\title{
Association of warfarin dose with genes involved in its action and metabolism
}

\author{
Mia Wadelius • Leslie Y. Chen • Niclas Eriksson • \\ Suzannah Bumpstead • Jilur Ghori · Claes Wadelius • \\ David Bentley • Ralph McGinnis • Panos Deloukas
}

Received: 6 July 2006 / Accepted: 1 September 2006 / Published online: 18 October 2006

(C) Springer-Verlag 2006

\begin{abstract}
We report an extensive study of variability in genes encoding proteins that are believed to be involved in the action and biotransformation of warfarin. Warfarin is a commonly prescribed anticoagulant that is difficult to use because of the wide interindividual variation in dose requirements, the narrow therapeutic range and the risk of serious bleeding. We genotyped 201 patients for polymorphisms in 29 genes in the warfarin interactive pathways and tested them for association with dose requirement. In our study, polymorphisms in or flanking the genes VKORC1, CYP2C9, CYP2C18, CYP2C19, PROC, APOE, EPHX1, CALU, GGCX and ORM1-ORM2 and haplotypes of VKORC1, CYP2C9, CYP2C8, CYP2C19, PROC, F7, GGCX, PROZ, F9, NR1I2 and ORM1-ORM2 were
\end{abstract}

Electronic supplementary material Supplementary material is available in the online version of this article at http://dx.doi.org/ $10.1007 / \mathrm{s} 00439-006-0260-8$ and is accessible for authorized users.

M. Wadelius

Department of Medical Sciences, Clinical Pharmacology,

University Hospital, 75185 Uppsala, Sweden

L. Y. Chen $\cdot$ S. Bumpstead $\cdot$ J. Ghori $\cdot$ D. Bentley

R. McGinnis · P. Deloukas $(\varangle)$

The Wellcome Trust Sanger Institute,

Wellcome Trust Genome Campus,

Hinxton, Cambridgeshire, CB10 1SA, UK

e-mail: panos@sanger.ac.uk

N. Eriksson

UCR-Uppsala Clinical Research Center,

Uppsala Science Park, 75183 Uppsala, Sweden

C. Wadelius

Department of Genetics and Pathology, Medical Genetics,

Rudbeck Laboratory, 75185 Uppsala, Sweden associated with dose $(P<0.05)$. VKORC1, CYP2C9, $C Y P 2 C 18$ and $C Y P 2 C 19$ were significant after experiment-wise correction for multiple testing $(P<0.000175)$, however, the association of $C Y P 2 C 18$ and $C Y P 2 C 19$ was fully explained by linkage disequilibrium with $C Y P 2 C 9 * 2$ and/or *3. $P R O C$ and $A P O E$ were both significantly associated with dose after correction within each gene. A multiple regression model with VKORC1, CYP2C9, PROC and the non-genetic predictors age, bodyweight, drug interactions and indication for treatment jointly accounted for $62 \%$ of variance in warfarin dose. Weaker associations observed for other genes could explain up to $\sim 10 \%$ additional dose variance, but require testing and validation in an independent and larger data set. Translation of this knowledge into clinical guidelines for warfarin prescription will be likely to have a major impact on the safety and efficacy of warfarin.

\section{Abbreviations}

ABCB1 ATP-binding cassette transporter B1

gene, P-glycoprotein gene or MDR1

APOE Apolipoprotein E

CALU Calumenin gene

CAR

CYP1A1

CYP1A2

CYP2A6

CYP2C18

CYP2C19

CYP2C8

CYP2C9

CYP3A4

CYP3A5

EPHX1
Constitutive androstane receptor

Cytochrome $P_{450} 1 \mathrm{~A} 1$

Cytochrome $P_{450} 1 \mathrm{~A} 2$

Cytochrome $P_{450} 2 \mathrm{~A} 6$

Cytochrome $P_{450} 2 \mathrm{C} 18$

Cytochrome $P_{450} 2 \mathrm{C} 19$

Cytochrome $P_{450} 2 \mathrm{C} 8$

Cytochrome $P_{450} 2 \mathrm{C} 9$

Cytochrome $P_{450} 3 \mathrm{~A} 4$

Cytochrome $P_{450} 3 \mathrm{~A} 5$

Epoxide hydrolase 1, microsomal gene 
F2

$\begin{array}{ll}\text { F5 } & \text { bin gene } \\ \text { F7 } & \text { Coagulation factor V gene } \\ \text { F9 } & \text { Coagulation factor VII gene } \\ \text { F10 } & \text { Coagulation factor IX gene } \\ \text { FII } & \text { Coagulation factor II or prothrombin }\end{array}$

FIIa Coagulation factor II activated or thrombin

FIX Coagulation factor IX

FIXa Coagulation factor IX activated

FV Coagulation factor $\mathrm{V}$

FVII Coagulation factor VII

FVIIa Coagulation factor VII activated

FX Coagulation factor $\mathrm{X}$

FXa

GAS6

GGCX

MDR1

NQO1

NR1I2

NR1I3

ORM1

ORM2

glycoprotein 2 gene

PCR Polymerase chain reaction

PROC Protein C gene

PROS1 Protein S gene

PROZ Protein Z gene

PT INR Prothrombin time international norma

lised ratio

PXR Pregnane X receptor

SERPINC1 Anti-thrombin III gene

siRNA Small interfering ribonucleic acid

SNP Single nucleotide polymorphism

UTR Untranslated region

VKORC1 Vitamin K epoxide reductase

complex subunit 1 gene

\section{Background}

Warfarin is one of the most widely used coumarin anticoagulants in the treatment of atrial fibrillation, heart valve prosthesis, recurrent stroke, deep vein thrombosis and pulmonary embolism (Daly and King 2003). However, its use is made difficult by the wide interindividual variation in dose required to achieve a therapeutic effect, the narrow therapeutic range, and the risk of serious bleeding (Landefeld and Beyth 1993). Warfarin dose requirement, which varies 20 -fold, is influenced by factors such as intake of vitamin K, ethnicity, illness, age, gender, concurrent medication, body mass index and genetic factors (Loebstein et al. 2001; Takahashi and Echizen 2003; Wadelius et al. 2004).

Warfarin acts through interference with the recycling of vitamin $\mathrm{K}$ in the liver, which leads to secretion of inactive vitamin K-dependent proteins (Bell et al. 1972; Dahlbäck 2005). Figure 1 shows the genes that are believed to be involved in the biotransformation of vitamin $\mathrm{K}$, warfarin and the vitamin K-dependent clotting factors, here called the warfarin interactive pathways (Supplementary Table S1; for details see Wadelius and Pirmohamed 2006). The main protein in the vitamin $\mathrm{K}$ epoxide reductase complex is encoded by VKORC1 (Li et al. 2004; Rost et al. 2004). Common variation in human $V K O R C 1$ is one of the most important genetic factors determining warfarin dose (D'Andrea et al. 2005; Geisen et al. 2005; Rieder et al. 2005; Sconce et al. 2005; Wadelius et al. 2005; Veenstra et al. 2005; Yuan et al. 2005). Another putative subunit of the vitamin $\mathrm{K}$ epoxide reductase is the microsomal epoxide hydrolase 1, encoded by $E P H X 1$, which harbours a vitamin K-epoxide binding site (Cain et al. 1997; Loebstein et al. 2005; Morisseau and Hammock 2005). Calumenin, encoded by $C A L U$, binds to vitamin $\mathrm{K}$ epoxide reductase and inhibits the effect of warfarin (Wallin et al. 2001; Wajih et al. 2004).

A high intake of the fat-soluble vitamin $\mathrm{K}_{1}$ can reverse the action of warfarin. Vitamin $\mathrm{K}_{1}$ is absorbed from the small intestine along with dietary fat, and subsequently cleared by the liver through an apolipoprotein E (APOE) receptor specific uptake (Berkner and Runge 2004). The uptake of vitamin $\mathrm{K}_{1}$ into the liver varies between different $A P O E$ alleles and is in the order of $* E 2<* E 3<* E 4$ (Saupe et al. 1993; Kohlmeier et al. 1996). It has also been suggested that the antioxidant enzyme nicotine adenine dinucleotide phosphate $(\mathrm{NAD}(\mathrm{P}) \mathrm{H})$ dehydrogenase, encoded by NQO1, has the potential to reduce dietary vitamin K (Wallin and Hutson 1982; Berkner and Runge 2004).

Reduced vitamin $\mathrm{K}$ is the essential cofactor for the activation of vitamin K-dependent proteins by gammaglutamyl carboxylase, encoded by $G G C X$ (Wu et al. 1997; Berkner 2000). The main vitamin K-dependent proteins are clotting factors II, VII, IX and X, proteins $\mathrm{C}, \mathrm{S}$ and $\mathrm{Z}$, and the growth-arrest specific protein 6 , encoded by F2, F7, F9, F10, PROC, PROS1, PROZ and GAS6, respectively (Berkner and Runge 2004). A non-vitamin K-dependent clotting protein anti-thrombin III, encoded by SERPINC1, inhibits the vitamin Kdependent factors II, IX and X (Dahlbäck 2005). Furthermore, the point mutation Arg506Gln (FV Leiden) 
Fig. 1 An overview of the interaction between warfarin and the 29 genes. This pathway illustrates genes thought to mediate the effects of warfarin. It also depicts a simplified representation of the biotransformation of warfarin and vitamin $\mathrm{K}$

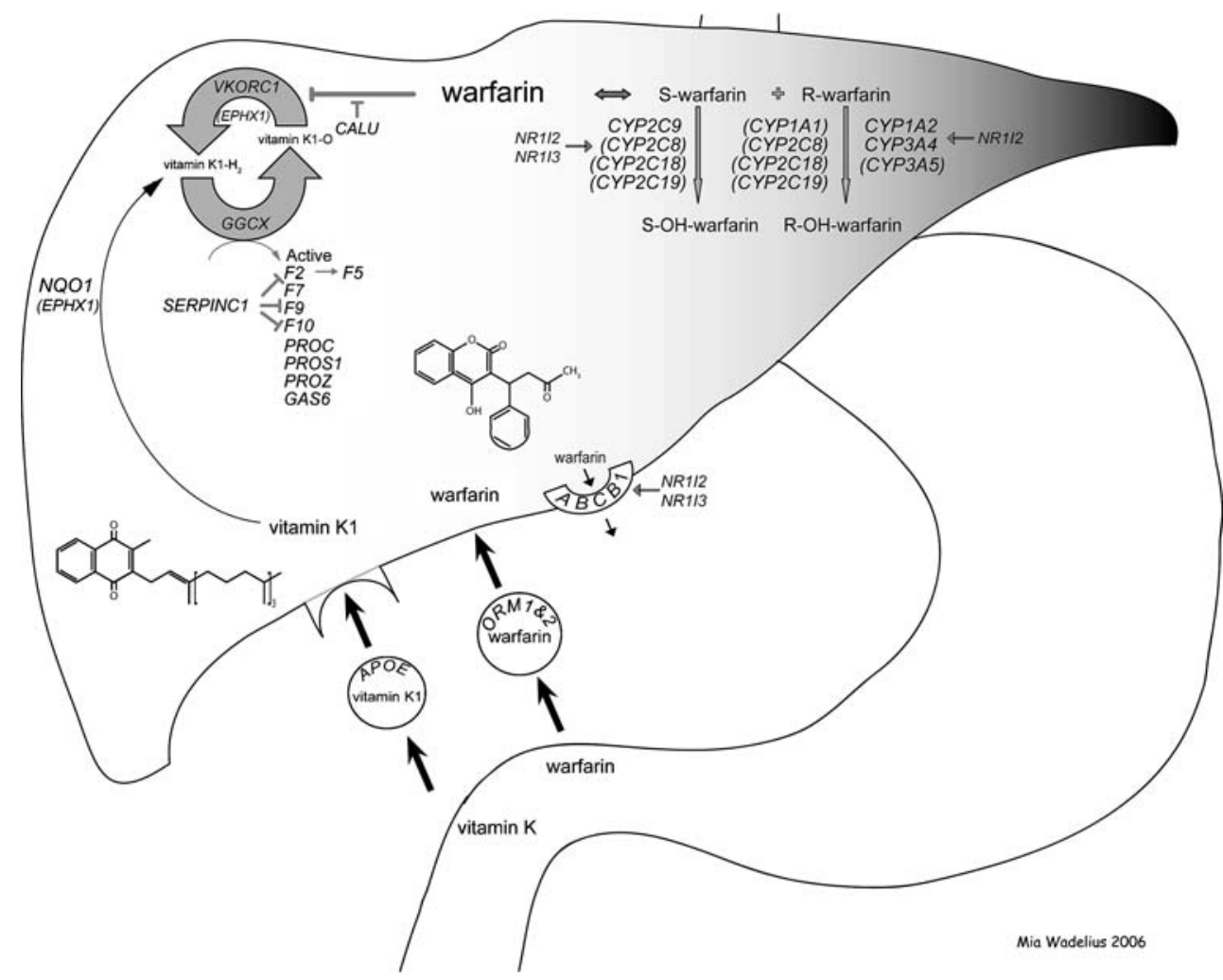

in $F 5$ is a common cause of thromboembolism, and is therefore a known cause of warfarin treatment (Larsen et al. 1998).

The molecular basis of warfarin pharmacokinetics has been extensively studied (Sanderson et al. 2005). Warfarin is administered as a racemate that consists of R- and S-enantiomers, the S-form being 3-5 times more active than the R-form (Rettie et al. 1992). Warfarin is rapidly absorbed from the stomach and the upper gastrointestinal tract (Palareti and Legnani 1996), and in the circulating blood it is highly bound to albumin and alpha 1-acid glycoproteins, encoded by ORM1 and ORM2 (Otagiri et al. 1987). Once warfarin has entered the liver, S-warfarin is metabolised by cytochrome $P_{450}$ 2C9 (CYP2C9) (Rettie et al. 1992; Kaminsky and Zhang 1997). Patients with CYP2C9 variant alleles $* 2$ and $* 3$ alleles (http://www.imm.ki.se/ CYPalleles/) require lower mean daily warfarin doses than extensive metabolisers homozygous for the *1 wild type allele do, and may have a greater risk of bleeding, especially during the induction of therapy (Sanderson et al. 2005). The enzymes CYP2C8, CYP2C18, CYP2C19 may also play a role in the metabolism of S-warfarin (Rettie et al. 1992; Kaminsky and Zhang 1997). R-warfarin is mainly metabolised by CYP1A2 and CYP3A4 (Rettie et al. 1992; Zhang et al. 1995; Kaminsky and Zhang 1997). In addition, CYP1A1, CYP2C8, CYP2C18, CYP2C19 and CYP3A5 may be involved in the metabolism of R-warfarin (Rettie et al. 1992; Zhang et al. 1995; Kaminsky and Zhang 1997; Huang et al. 2004). Cytochrome $P_{450}$ enzymes are induced by the nuclear hormone receptors pregnane $\mathrm{X}$ receptor (PXR) and constitutive androstane receptor (CAR), which are encoded by NR1I2 and NR1I3 (Lehmann et al. 1998; Chen et al. 2004). Based on an inhibition assay, there is some evidence that transport of warfarin out of the liver and into the bile may be mediated by P-glycoprotein, which is encoded by $A B C B 1$ (MDR1) (Sussman et al. 2002). $\mathrm{P}$-glycoprotein can be induced by the nuclear hormone receptor PXR (Geick et al. 2001).

We and others have shown that common variants in the VKORC1 and CYP2C9 genes together with a limited subset of environmental determinants account for around $50-60 \%$ of the variance in warfarin dose requirement (Sconce et al. 2005; Wadelius et al. 2005; Veenstra et al. 2005; Aquilante et al. 2006; Lee et al. 2006; Takahashi et al. 2006; Vecsler et al. 2006). Here, we fine map the VKORC1 and the $C Y P 2 C$ gene cluster loci on chromosomes 16 and 10, respectively, and assess common variation in 27 other genes in the warfarin interactive pathways for association with dose requirements. Finally, we evaluate the potential contribution of all positively associated genes to a warfarin dose model, which includes age, bodyweight, concomitant medication and indication for treatment. 


\section{Methods}

\section{Subjects}

Two hundred and one Caucasian patients were recruited at Uppsala University Hospital in 2000; 194 patients of Swedish origin, four of other European descent and three from the Middle East (Wadelius et al. 2004). Their mean age was 66.7 years (range 2888 years), and $1 / 3$ of them were women. They had been treated with warfarin $\left(\right.$ Waran ${ }^{\circledR}$, Nycomed AB, Stockholm, Sweden) for a minimum of 2 months (range 2.4 months-26 years, median 2 years), and their prothrombin time international normalised ratio (PT INR) had been stabilised. At the six following visits, five weekly warfarin doses and five corresponding PT INR were registered. Individual warfarin dose requirement ranged from 4.5 to $77.25 \mathrm{mg} /$ week. Information about age, gender, bodyweight (missing in seven patients), treatment indication and duration, other diseases and concurrent medication was taken from the patients' medical records, and the details have been presented previously (Wadelius et al. 2004, 2005). Patients were stratified into two groups depending on indication for treatment: patients with heart valve prosthesis $(n=49)$, where a higher target INR usually is recommended, and patients treated for other indications such as atrial fibrillation $(n=113)$, thromboembolic disease $(n=9)$, cardiomyopathy $(n=8)$ and transischemic attack $(n=5)$. Concurrent medications were registered, and drugs were classified as interacting if they had moderate or major interactions with warfarin according to the database MICROMEDEX ${ }^{\circledR}$ Healthcare Series (http://www.micromedex.com/) (May 2002). The patients had a total of 107 concurrent medications known to influence warfarin. They were divided into three groups: individuals with drugs that lower the effect of warfarin by inducing its metabolism $(n=4)$, those with medications that potentiate the effect of warfarin $(n=74)$ and patients without any known interactions $(n=123)$. The study was approved by the local Ethics Committee.

\section{Genotyping}

DNA was extracted from whole blood using QIAamp ${ }^{\circledR}$ DNA Blood Mini Kit (QIAGEN Ltd., Crawley, UK). Within the 29 candidate genes including $5 \mathrm{~kb}$ up- and downstream flanking regions, we selected available single nucleotide polymorphisms (SNPs), preferably with minor allele frequency (MAF) $>5 \%$ and spread out as evenly as possible every $2-5 \mathrm{~kb}$. The first set of SNPs was selected from dbSNP (http://www.ncbi.nlm.nih.
gov/projects/SNP/) prior to the HapMap (http://www. hapmap.org/index.html.en), which was later used for gap filling in regions where the tested SNPs failed or were monomorphic in our population. In addition, we mined functional polymorphisms from the literature. In the process circa 900 SNPs were tested. SNP assays were designed with the SpectroDESIGNER ${ }^{\mathrm{TM}}$ software.

The $G G C X$ microsatellite marker in intron 6 was analysed as described earlier (Chen et al. 2005). SNP typing was performed with the Homogeneous Mass Extend assay (Sequenom, Hamburg, Germany). Polymerase chain reaction (PCR) amplification was performed in $5-\mu \mathrm{L}$ reactions using $3.5 \mathrm{ng}$ DNA and $150 \mathrm{nM}$ of each forward and reverse primer, $200 \mu \mathrm{M}$ deoxynucleotide triphosphates (dNTPs), $1 \times$ PCR buffer, and $0.04 \mathrm{U}$ Titanium ${ }^{\circledR}$ polymerase (BD BioSciences, Clontech, CA, USA). Cycling conditions were $94^{\circ} \mathrm{C}$ for $15 \mathrm{~min}$, followed by 45 cycles of $94^{\circ} \mathrm{C}$ for $20 \mathrm{~s}, 56^{\circ} \mathrm{C}$ for $30 \mathrm{~s}$ and $72^{\circ} \mathrm{C}$ for $1 \mathrm{~min}$, and then $72^{\circ} \mathrm{C}$ for $3 \mathrm{~min}$. Primer extension, sample clean up and MALDI-TOF Mass Spectrometry analysis were performed as described elsewhere (Whittaker et al. 2006). Primer sequences are available on request.

Genotyping was carried out at a multiplex level of four SNPs per well and data quality was assessed by duplicate DNA $(n=4)$. SNPs with more than one discrepant call or showing self-priming in the negative control (water) were removed. Finally, we removed non-polymorphic SNPs, SNPs with call rate below $70 \%$, and markers that departed from Hardy Weinberg equilibrium $(P<0.001)$.

\section{Statistical analysis}

Univariate and multiple analyses of predictor's impact on the square root of warfarin dose were calculated using linear regression models as implemented by SAS and SPLUS software. To account for partial dependence among tests of SNPs in linkage disequilibrium (LD), we applied both the Bonferroni correction for multiple testing based on calculating the effective number of independent tests $\left(M_{\text {eff }}\right)$ and a Permutation procedure (Cheverud 2001; Li 2001; Nyholt 2004). LD was visualised using the HaploView software (Gabriel et al. 2002). The QTPHASE component of UNPHASED software was used to estimate haplotype frequencies, calculate means and variances of warfarin dose associated with each haplotype, and statistically test for differences among the haplotype means (Dudbridge 2003). Pairwise LD was quantified by the standard $r^{2}$ measure (Pritchard and Przeworski 2001). The proportion of explained variance (coefficient of determination) was measured by $R^{2}$. 


\section{Results and discussion}

Association of warfarin dose with individual markers

We selected 29 candidate genes in the warfarin interactive pathways (Fig. 1 and Supplementary Table S1) and tested them for $\sim 800$ SNPs that comprehensively captured common variation based on measures of LD $\left(r^{2} \geq 0.8\right)$. In addition, we tested almost 100 functional polymorphisms including several published variants reported to be associated with warfarin dose, however, most of the tested functional SNPs were later excluded due to being monomorphic or having very low MAF. We identified 348 SNPs (Supplementary Table S2) that passed quality control and had a MAF of at least $4 \%$ in our sample of 201 warfarin patients. Note that results for VKORC1, GGCX and CYP2C9 are based on the reanalysis of SNPs presented by Wadelius et al. (2005) together with additional SNPs typed in this study. Univariate regression analysis showed that 32 polymorphisms in or flanking the genes VKORC1, CYP2C9, CYP2C19, CYP2C18, PROC, EPHX1, CALU, $G G C X, O R M 1$ and $O R M 2$ were nominally associated with warfarin dose requirement (Table 1 ). In addition, the two polymorphisms that discriminate between $A P O E^{*} E 2,{ }^{*} E 3$ and $* E 4$ were significantly associated with dose when assessed together (Table 1). In determining correction for multiple testing, we compared the Permutation procedure with the Bonferroni correction based on the effective number of independent traits (Bonferroni $M_{\text {eff }}$ ) and found that the two methods yielded very similar $P$-value cut-points (Cheverud 2001; Li 2001; Nyholt 2004). In this study, we present the number of effective tests within each gene obtained by the Bonferroni $M_{\text {eff }}$ method. The number of independent effective tests within each gene or gene cluster varied from 2 to 50, implying gene-wise corrected cutpoints of $P<0.025$ to $<0.001$. Assuming that the genes are independent of each other, the sum of effective tests over all genes was 285 . This makes $P<0.05 / 285$, which equals $P<0.000175$, the cut-off level for experiment-wise significance. Using this cut-point, VKORC1, $C Y P 2 C 9, C Y P 2 C 18$ and $C Y P 2 C 19$, were associated with dose after experiment-wise correction for multiple testing, while $P R O C$ and $A P O E$ were significant only after within-gene correction (Table 1). Ten $F 2$ SNPs, 41 F5 SNPs, 11 F7 SNPs, 11 F9 SNPs, 15 F10 15 SNPs, 13 PROZ SNPs, 11 PROS1 SNPs, four GAS6 SNPs, nine SERPINC1 SNPs, nine NQO1 SNPs, three $C Y P 1 A 1$ SNPs, three $C Y P 1 A 2$ SNPs, two $C Y P 3 A 4$ SNPs, seven $C Y P 3 A 5$ SNPs, $12 C Y P 2 C 8$ SNPs, 20 NR112 SNPs, nine NR1I3 SNPs and $38 A B C B 1$ SNPs passed the study criteria, but none of them were signifi- cantly associated with warfarin dose (Supplementary Table S2).

Association of warfarin dose with haplotypes

Haplotype analysis showed 12 genes to be nominally associated with warfarin dose (Table 2), namely VKORC1, CYP2C9, CYP2C8, CYP2C19, PROC, F7, GGCX, PROZ, F9, NRII2 and ORM1-ORM2. Compared with the univariate single-marker analysis, four additional genes, F7, PROZ, F9 and NR1I2 were associated at $P<0.05$. The haplotypes that exhibited the lowest $P$-values in each candidate gene are listed in Table 2. VKORC1, CYP2C9, CYP2C18 and CYP2C19 showed experiment-wise significance for haplotype analysis, as they did for single markers. Likewise, PROC was significant at a gene-wise level.

Fine mapping of the $V K O R C 1$ and $C Y P 2 C$ regions

VKORC1 on chromosome 16 was the single gene most strongly associated with warfarin dose (Tables 1, 2). We previously described five SNPs in $V K O R C 1$ in an extended region of high LD spanning over $300 \mathrm{~kb}$ in the Swedish sample (Fig. 2). In this sample, three of the SNPs (rs2359612, rs9934438, rs9923231) were perfectly correlated with pairwise LD $r^{2}$-values of $\sim 1.0$ and accounted for $\sim 30 \%$ of the warfarin dose variance $\left(R^{2}\right)$ (Wadelius et al. 2005). An important goal of this study was to fine map $V K O R C 1$. Each of ten additional SNPs in the VKORC1 region (Fig. 2a) was tested to determine if it added significantly more dose variance to a multiple regression model that included one of the three linked SNPs (rs2359612), CYP2C9 $* 2$ and $* 3$, and non-genetic predictors of warfarin dose (Supplementary Table S3). Our results demonstrated that: (a) each of the three linked SNPs predicted more dose variance ( $\sim 30 \%)$ than any other genotyped VKORC1 SNP, and (b) none of the other ten flanking SNPs predicted additional dose variance (Fig. 2). In accordance, no VKORC1 haplotype yielded association $P$-values more significant than the three linked SNPs (Tables 1,2). The molecular mechanism by which the three linked SNPs influence warfarin response has not been resolved. Due to the high LD between the three SNPs in our population, it is not possible to discern which of them that is responsible for the effect on warfarin. None of the studied SNPs are coding, and thus do not alter protein structure. Instead the effect may be mediated by altering the amount of drug target in the liver as postulated by studies showing that VKORC1 $5^{\prime}$ SNPs are correlated with liver levels of mRNA (Rieder et al. 2005) and with activity in a reporter assay (Yuan 
Table 1 Genes with significant association with warfarin dose, based on univariate regression of square root of dose

\begin{tabular}{|c|c|c|c|c|c|c|}
\hline Gene & SNP & MAF & $n$ & Univariate $R^{2}$ & $P$-Value & $\begin{array}{l}r^{2} \text { with best } \\
\text { SNP }\end{array}$ \\
\hline \multirow[t]{11}{*}{$V K O R C 1$} & rs9923231 & 0.391 & 181 & 0.317 & $1.91 \times 10^{-15 * *}$ & - \\
\hline & rs 2359612 & 0.389 & 200 & 0.290 & $2.30 \times 10^{-15 * *}$ & 0.968 \\
\hline & rs9934438 & 0.383 & 169 & 0.292 & $3.59 \times 10^{-13 * *}$ & 1.000 \\
\hline & rs7294 & 0.384 & 188 & 0.208 & $4.14 \times 10^{-10 * *}$ & 0.385 \\
\hline & rs4889490 & 0.446 & 199 & 0.160 & $3.821 \times 10^{-8 * *}$ & 0.461 \\
\hline & rs4889537 & 0.372 & 199 & 0.142 & $3.158 \times 10^{-7 * *}$ & 0.209 \\
\hline & rs4889599 & 0.366 & 194 & 0.124 & $3.270 \times 10^{-6 * *}$ & 0.305 \\
\hline & rs8046978 & 0.214 & 197 & 0.047 & 0.00906 & 0.173 \\
\hline & rs11642603 & 0.093 & 192 & 0.027 & 0.02304 & 0.070 \\
\hline & rs11642466 & 0.103 & 195 & 0.025 & 0.02623 & 0.080 \\
\hline & rs7194347 & 0.343 & 197 & 0.032 & 0.04069 & 0.153 \\
\hline \multirow[t]{7}{*}{ CYP2C9 } & rs1057910 (*3) & 0.058 & 201 & 0.141 & $2.784 \times 10^{-7 * *}$ & - \\
\hline & rs9332108 & 0.064 & 201 & 0.141 & $2.784 \times 10^{-7 * *}$ & 0.890 \\
\hline & rs9325473 & 0.055 & 189 & 0.147 & $3.753 \times 10^{-7 * *}$ & 0.908 \\
\hline & rs1057911 & 0.067 & 191 & 0.145 & $4.218 \times 10^{-7 * *}$ & 0.890 \\
\hline & rs9332214 & 0.059 & 198 & 0.139 & $4.654 \times 10^{-7 * *}$ & 0.878 \\
\hline & rs4917639 & 0.173 & 197 & 0.118 & $4.944 \times 10^{-6 * *}$ & 0.276 \\
\hline & rs2860905 & 0.214 & 193 & 0.072 & $0.00080 *$ & 0.224 \\
\hline \multirow[t]{2}{*}{ СУР2C19 } & rs3814637 & 0.059 & 195 & 0.106 & $0.00002 * *$ & $0.838^{\mathrm{a}}$ \\
\hline & rs17882687(*15) & 0.08 & 183 & 0.044 & $0.00417 *$ & $0.395^{\mathrm{a}}$ \\
\hline CYP2C18 & rs7896133 & 0.056 & 193 & 0.074 & $0.00013 * *$ & $0.869^{\mathrm{a}}$ \\
\hline \multirow[t]{4}{*}{ PROC } & rs2069919 & 0.372 & 182 & 0.090 & $0.00022 *$ & - \\
\hline & rs1799809 & 0.433 & 188 & 0.078 & $0.00055^{*}$ & 0.777 \\
\hline & rs2069901 & 0.441 & 177 & 0.072 & $0.00147 *$ & 0.785 \\
\hline & rs2069910 & 0.387 & 178 & 0.046 & 0.01678 & 0.414 \\
\hline$A P O E$ & rs $429358+$ rs7412b & 0.251 & 201 & 0.051 & $0.00570 *$ & - \\
\hline EPHX1 & rs 4653436 & 0.266 & 196 & 0.048 & 0.00848 & - \\
\hline \multirow[t]{4}{*}{$C A L U$} & rs11653 & 0.366 & 197 & 0.047 & 0.00944 & - \\
\hline & rs1006023 & 0.331 & 200 & 0.033 & 0.03789 & 0.865 \\
\hline & rs2307040 & 0.336 & 200 & 0.033 & 0.03811 & 0.867 \\
\hline & rs339054 & 0.461 & 195 & 0.032 & 0.04487 & 0.612 \\
\hline$G G C X$ & rs12714145 & 0.408 & 198 & 0.034 & 0.03320 & - \\
\hline ORM1-2 & rs1687390 & 0.062 & 149 & 0.026 & 0.04964 & - \\
\hline
\end{tabular}

The SNPs are listed with the lowest $P$-value first. The LD $\left(r^{2}\right)$ between the SNP with the lowest $P$-value and others in the gene or gene cluster is shown. $n$ is the number of successfully genotyped individuals

${ }^{\text {a }}$ Linkage disequilibrium with $C Y P 2 C 9 * 3$ (rs10579103)

b Note that the two APOE SNPs are not significant individually, only when assessed as E2 + E4 vs. E3

*The test is significant, based on correction for the effective number of tests in each gene or gene cluster

$* *$ Corresponds to experiment-wise significance, based on $\sim 285$ independent effective tests $\left(P<1.75 \times 10^{-4}\right)$

et al. 2005); however, a third study failed to show this (Bodin et al. 2005).

The $C Y P 2 C$ gene cluster on chromosome 10 was the second most strongly associated region after $V K O R C 1$ (Tables 1,2). This region of high LD includes $C Y P 2 C 9$, $C Y P 2 C 8, C Y P 2 C 18$ and $C Y P 2 C 19$ (Supplementary Fig. S1). Several $C Y P 2 C$ SNPs were associated with warfarin dose, even after correction for multiple testing. The functional polymorphism in $C Y P 2 C 9 * 3$ (rs1057910, I359L), which severely impairs the capacity to hydroxylate S-warfarin (Haining et al. 1996), was the most strongly associated SNP in this region (Table 1). The functional $C Y P 2 C 9 * 2$ polymorphism (rs1799853, R144C) confers only a moderate reduction in the metabolism of S-warfarin (Rettie et al. 1994), and was not significant in univariate analysis. In fine mapping of the $C Y P 2 C$ region, we successfully genotyped 53 additional SNPs: 17 in $C Y P 2 C 9$, ten in $C Y P 2 C 19,14$ in $C Y P 2 C 18$ and 12 in $C Y P 2 C 8$. In univariate analysis, significant association was observed for nine SNPs apart from *3 including the CYP2C19 5' upstream rs 3814637 , the $* 15$ allele and the intronic 
Table 2 Two or three marker haplotype giving the lowest $P$-value in each candidate gene

\begin{tabular}{|c|c|c|c|}
\hline Gene & Haplotype & $P$-value & Smaller? ${ }^{\mathrm{a}}$ \\
\hline VKORC1 & rs9934438-rs9923231 & $5.76 \times 10^{-15 * *}$ & No \\
\hline$C Y P 2 C 9$ & rs $9332214^{\mathrm{b}}$-rs $9332222^{\mathrm{c}}$-rs 2298037 & $4.86 \times 10^{-9 * *}$ & Yes \\
\hline CYP2C18 & rs1926711-rs7919273 ${ }^{\mathrm{b}}$-rs10509675 & $3.47 \times 10^{-7 * *}$ & Yes \\
\hline CYP2C19 & rs $2860840-r s 3814637^{\mathrm{b}}$ & $2.08 \times 10^{-6 * *}$ & Yes \\
\hline PROC & rs2069919-rs2069921-rs973760 & $1.36 \times 10^{-3 *}$ & No \\
\hline F7 & rs3093229-rs3093233 & $2.42 \times 10^{-2}$ & Yes \\
\hline$G G C X$ & Microsatellite $^{\mathrm{d}}$-rs762684-rs6738645 & $1.78 \times 10^{-2}$ & Yes \\
\hline PROZ & rs2273971-rs3024711 & $3.57 \times 10^{-2}$ & Yes \\
\hline F9 & rs401597-rs392959 & $3.83 \times 10^{-2}$ & Yes \\
\hline NR1I2 & rs2461818-rs7643645 & $3.93 \times 10^{-2}$ & Yes \\
\hline ORM1-2 & rs1687390-rs3762055 & $4.93 \times 10^{-2}$ & No \\
\hline
\end{tabular}

$P$-Values are arranged in ascending order and are based on QTPHASE haplotype test of association with square root of warfarin dose. Genes not shown did not produce a nominally significant $(P<0.05)$ haplotype result

a Yes indicates that the haplotype $P$-value is smaller than the $P$-value for the best single marker in the same gene

b Strongly associated with $C Y P 2 C 9 * 3$

c Strongly associated with $C Y P 2 C 9 * 2$

d GGCX microsatellite described by Chen at al. (2005)

*Gene-wise significance based on correcting for the effective number of tests in each gene. The other $P$-values are of nominal significance $(P<0.05)$

**Experiment-wise significance $\left(P<1.75 \times 10^{-4}\right)$

Fig. 2 Fine mapping of the VKORC1 locus. a Location of $\mathrm{SNP}$ markers $(\mathrm{MAF} \geq 5 \%)$ in $\mathrm{a} \sim 550 \mathrm{~kb}$ region surrounding $V K O R C 1$ which is coded on the reverse strand and is located at the right end of the LD block. Previously reported SNPs are shown in red (11). b The univariate $r^{2}$ (pink, left axis) and $P$-value (blue, right axis) are shown for each SNP. The black line near $10^{-3}$ on the right axis indicates the $P$-value that is necessary to achieve significance after within-gene Bonferroni correction. $\mathbf{c}$ HaploView analysis with pair-wise $r^{2}$ illustrating the extent of LD in the region. The red dotted triangle indicates the LD block defined with data of the HapMap project (CEU panel) a
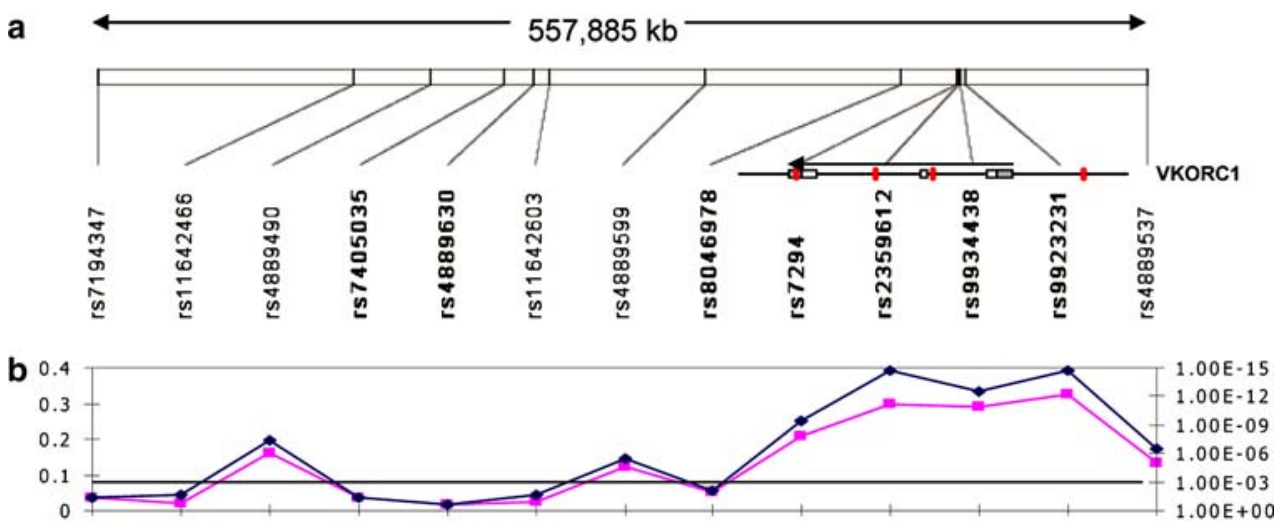

c

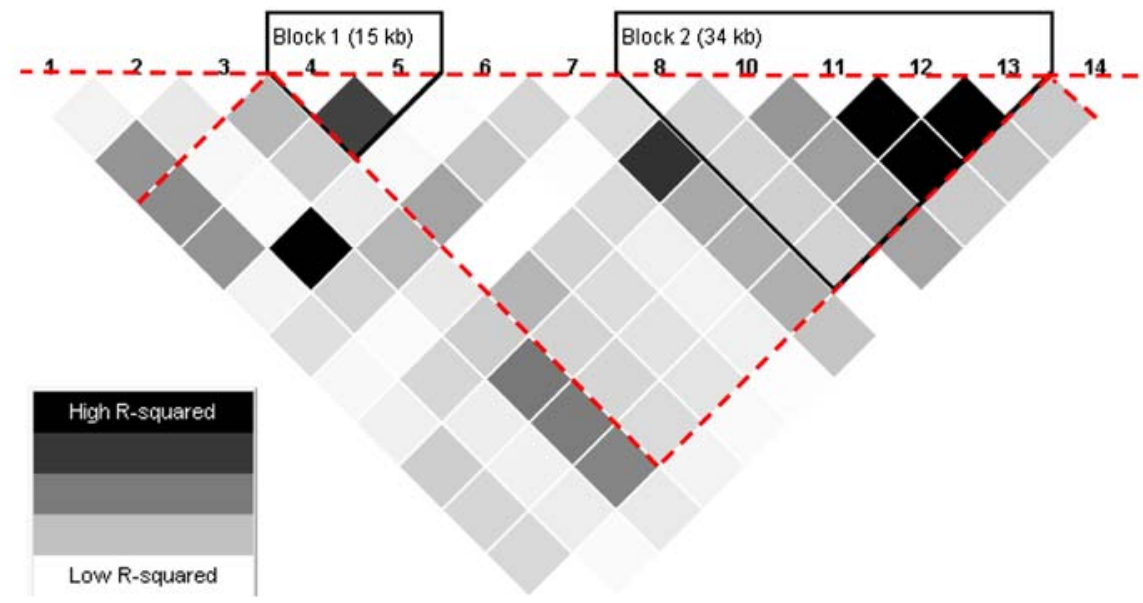

CYP2C18 rs7896133 (Table 1). The CYP2C19*2A allele, which leads to an inactive CYP2C19 enzyme, was in agreement with earlier studies not associated
(Takahashi et al. 1998; Scordo et al. 2002). To test whether any of the other $C Y P 2 C$ SNPs accounted for additional dose variance, apart from the 2.4 and $10.9 \%$ 
explained by $C Y P 2 C 9 * 2$ and $* 3$, two multiple regression models were used (Table 3 ). Both models contained VKORC1 (rs2359612) and significant non-genetic predictors of warfarin dose, whereas one contained $C Y P 2 C 9 * 2$ but not $* 3$ and vice versa. Each one of the 55 CYP2C SNPs was evaluated against the two multiple regression models. This showed that except for the CYP2C9 SNP rs4917639, all significant results were fully explained by LD with either $C Y P 2 C 9 * 2$ or *3. In contrast, $C Y P 2 C 9$ SNP rs4917639 gave a significant $P$-value in both the $* 2$ model $\left(P<1.33 \times 10^{-9}\right)$ and the $* 3$ model $\left(P<3.56 \times 10^{-3}\right)$. The minor allele of rs4917639 was in perfect LD $\left(r^{2}=1\right)$ with a composite minor allele formed by aggregating $C Y P 2 C 9 * 2$ and $* 3$ into a single allele, although $* 2$ and $* 3$ are rarely carried on the same haplotype (McGinnis et al. 2006). These data suggest that the rs4917639 mutation occurred first, and that rs1799853 and rs1057910, which are diagnostic for $* 2$ and $* 3$, arose independently on the same parent allele. The strong association between rs 4917639 and $* 2 / * 3$ could perhaps be due to positive selection, if rs4917639 lessened the deleterious effect of impaired CYP2C9 metabolism caused by $* 2$ and $* 3$. This and related possibilities merit further investigation given the unusual pattern of LD between rs4917639 and $* 2 / * 3$.
Other genes tentatively associated with warfarin dose

Of the 13 PROC SNPs included in the analysis, four were significantly associated with dose: rs1799809 $\mathrm{A}>\mathrm{G}$ and rs2069901 $\mathrm{T}>\mathrm{C}$ in the $5^{\prime}$ regulatory region of $P R O C$, rs $2069910 \mathrm{C}>\mathrm{T}$ in intron 2 and rs2069919 $\mathrm{G}>\mathrm{A}$ in intron 3 (Table 1). The two promoter polymorphisms and the intron 3 polymorphism reached gene-wise significance and explained 7-9\% of the variance in warfarin dose; $P=0.0002-0.0015$. Haplotypes of $P R O C$ were also significantly associated with dose, but did not increase the statistical confidence since the lowest $P$-value was 0.00136 (Table 2). Unlike most other vitamin $\mathrm{K}$-dependent factors, protein $\mathrm{C}$ acts as a natural anticoagulant by inactivating factors $\mathrm{Va}$ and VIIIa, but all its activities are not yet fully understood (Dahlbäck 2005). Intriguingly, it has previously been shown that protein $\mathrm{C}$ activity is negatively correlated with PT INR, not only in patients treated with oral anticoagulants, but also in healthy subjects and in medical patients without oral anticoagulants (Watala et al. 2003). Two other studies have found that homozygosity for the $\mathrm{G}$ allele of the PROC promoter polymorphism rs1799809 is associated with slightly reduced concentrations and activities of protein C (Spek et al. 1995; Aiach et al. 1999). In our study, carriers of

Table 3 Significant $(P<0.05)$ regression results for SNPs in the CYPC2 gene cluster

\begin{tabular}{|c|c|c|c|c|c|}
\hline Gene & SNP & $R^{2}$ with $* 2$ model & $P$-Value & $R^{2}$ with $* 3$ model & $P$-Value \\
\hline СYР2C8 & rs11572080 & 0.001 & 0.502 & 0.017 & 0.005 \\
\hline$C Y P 2 C 9$ & rs9332108 & 0.109 & $1.57 \times 10^{-10}$ & 0.000 & 0.999 \\
\hline CYP2C9 & rs1057910 (*3) & 0.109 & $1.57 \times 10^{-10}$ & - & - \\
\hline$C Y P 2 C 9$ & rs1057911 & 0.114 & $2.97 \times 10^{-10}$ & 0.000 & 0.999 \\
\hline$C Y P 2 C 9$ & rs9325473 & 0.112 & $5.45 \times 10^{-10}$ & 0.000 & 0.999 \\
\hline$C Y P 2 C 9$ & rs4917639 & 0.100 & $1.33 \times 10^{-9}$ & 0.025 & $3.56 \times 10^{-3}$ \\
\hline CYP2C9 & rs9332214 & 0.098 & $1.50 \times 10^{-9}$ & 0.000 & 0.999 \\
\hline$C Y P 2 C 9$ & rs2860905 & 0.048 & $1.86 \times 10^{-4}$ & 0.009 & 0.153 \\
\hline$C Y P 2 C 9$ & rs4917636 & 0.004 & 0.213 & 0.026 & $3.63 \times 10^{-3}$ \\
\hline$C Y P 2 C 9$ & rs4607998 & 0.004 & 0.252 & 0.026 & $2.85 \times 10^{-3}$ \\
\hline CYP2C9 & rs1799853 (*2) & - & - & 0.024 & $4.00 \times 10^{-3}$ \\
\hline CYP2C9 & rs1934966 & 0.000 & 0.999 & 0.015 & $8.72 \times 10^{-3}$ \\
\hline CYP2C9 & rs9332222 & 0.000 & 0.999 & 0.025 & $3.86 \times 10^{-3}$ \\
\hline CYP2C18 & rs7896133 & 0.063 & $5.17 \times 10^{-7}$ & 0.000 & 0.999 \\
\hline СУР2C18 & rs2901783 & 0.020 & 0.029 & 0.004 & 0.471 \\
\hline СYР2C19 & rs3814637 & 0.098 & $3.76 \times 10^{-9}$ & 0.000 & 0.896 \\
\hline СYР2C19 & rs17882687 & 0.047 & $5.19 \times 10^{-5}$ & 0.000 & 0.828 \\
\hline
\end{tabular}

Additional dose variance $\left(R^{2}\right)$ explained by each SNP and the corresponding $P$-value is shown for two multiple regression models of warfarin dose. Both models contain VKORC1 SNP rs2359612 and non-genetic predictors identified by Wadelius et al. (2005). $C Y P 2 C 9 * 2$ is included in the first alternative regression model and $C Y P 2 C 9 * 3$ is included in the second model. A non-significant $P$-value for the $* 2$ model but highly significant result for the $* 3$ model implies that $* 2$ fully accounts for the tested SNP's contribution to dose variance (and vice versa). Thus, $* 2$ or $* 3$ fully account for each tested SNP apart from rs4917639

SNPs giving non-significant $(P>0.05)$ results in both models are: CYP2C8 (rs2275622, rs7898759, rs1557044, rs2275620, rs1341163, rs1891071, rs1058932, rs1058930, rs947173, rs17110453, rs3752988); CYP2C9 (rs9332197, rs2475376, rs1856908, rs1934964, rs2153628, rs10509679, rs2298037); CYP2C18 (rs10736086, rs10509675, rs12249418, rs7099637, rs7898763, rs7919273, rs1926706, rs2281891, rs1926711, rs7478002, rs2860837, rs2860840); CYP2C19 (rs4244284, rs12248560, rs3758580, rs4250786, rs17879456, rs17882419, rs4417205, rs1853205) 
rs1799809 G/G, had lower dose requirements than others $(P=0.00055)$. If $\mathrm{rs} 1799809 \mathrm{G} / \mathrm{G}$ individuals have a reduced pre-treatment protein $\mathrm{C}$ activity (Spek et al. 1995; Aiach et al. 1999), which according to Watala et al. (2003) is associated with higher PT INR, then this might explain their low-warfarin dose requirements. However, this theory needs to be tested in a larger population. A Japanese group previously failed to find an association between warfarin dose and the rare synonymous coding PROC SNP rs5935 (Shikata et al. 2004), which was not polymorphic in our sample.

We analysed the two $A P O E$ SNPs that define the widely used $* E 2$, $* E 3$ and $* E 4$ allelic system. Patients who carried the common allele $* E 4$ or the rarer $* E 2$ required higher warfarin doses than those with ${ }^{*} E 3$; $P=0.0057$. This result was significant after within-gene correction for multiple testing (Table 1). We previously reported that CYP2C9 extensive metabolisers who were homozygous for $A P O E^{*} E 4$ required higher warfarin doses than other extensive metabolisers; $P=0.0008$ (Kohnke et al. 2005b). This is supported by a Dutch study that found slightly higher maintenance doses of the anticoagulant phenprocoumon in $A P O E^{*} E 4$ homozygous individuals (Visser et al. 2005). Surprisingly, the same study found that $A P O E^{*} E 4$ carriers required lower maintenance doses of acenocoumarol. No homozygous $* E 4$ individuals were found among Italian patients, and the association between warfarin dose requirements and $A P O E$ genotype was not seen (Kohnke et al. 2005a). These discrepant results indicate that the association between anticoagulant dose and $A P O E$, if any, is weak. In addition, they point out that a future warfarin dose prediction model may not be applicable to phenprocoumon and acenocoumaron.

Nine other genes were nominally associated with warfarin dose, but did not pass correction for multiple testing: GGCX, F7, PROZ, F9, EPHX1, CALU, NR1I2, ORM1 and ORM2 (Tables 1, 2). It has been shown that warfarin dose tends to increase with the number of repeats of a microsatellite in intron 6 of GGCX (Shikata et al. 2004; Chen et al. 2005). A haplotype including the microsatellite was more significant than the intron 2 SNP rs12714145 reported by Chen et al. (2005), however, both failed to reach gene-wise significance (Tables 1, 2). The SNP rs5896 causing a threonine to methionine change at position 165 in the prothrombin gene (F2), which was reported to confer warfarin sensitivity (D'Ambrosio et al. 2004; Shikata et al. 2004), did not replicate in our study; $P=0.2923$. $F 7, F 10$ and $P R O Z$ are positioned in close proximity, and $F 7$ promoter polymorphisms are claimed to have an effect on warfarin sensitivity (D'Ambrosio et al.
2004; Shikata et al. 2004; Aquilante et al. 2006). A haplotype located $2 \mathrm{~kb}$ upstream of $F 7$ was tentatively associated with dose, and so was a PROZ haplotype comprising SNPs $5^{\prime}$ upstream of the gene and in the first intron (Table 2). On the other hand, the coding $F 7$ SNP rs6046 (R413Q, formerly R353Q) that may lead to decreased plasma levels of factor VII (Arbini et al. 1994), and the synonymous SNP rs5960 in the exon 7 of F10 did not affect warfarin dosing (Shikata et al. 2004). The rare variant in $F 9(\mathrm{~A}-10 \mathrm{~V} / \mathrm{T})$ that causes a disproportional reduction in factor IX activity in warfarintreated patients (Kristensen 2002; van der Heijden et al. 2004) was not found in our study population, although a haplotype covering this region showed nominal association to dose (Table 2). A recent study has shown an association between high doses of warfarin in CYP2C9 extensive metabolisers carrying the non-synonymous EPHX1 SNP rs1051740 which results in a tyrosine to histidine substitution at residue 113 (Loebstein et al. 2005). We failed to replicate this finding, although rs4653436 located 5' upstream was nominally associated with dose (Table 1 ). A coding SNP in $C A L U$ (R4Q), that is suspected to increase warfarin dose requirement in $C Y P 2 C 9$ and $V K O R C 1$ wild type patients (Vecsler et al. 2006), was not significantly associated with dose in our study. However, the $3^{\prime}$ UTR $C A L U$ SNP rs11653, the non-synonymous rs 2307040 and the two intronic rs339054 and rs1006023 gave borderline significant $P$-values (Table 1 ). The nominal association between warfarin dose requirements and a haplotype of NR1I2 has to our knowledge not previously been shown (Table 2). Warfarin's association with rs3762055 located between ORM1 and ORM2, and with a haplotype covering this region are also novel findings (Tables 1,2). The weaker associations observed for these tentatively associated genes require testing and validation in an independent and larger data set. Finally, it is worth mentioning that the prothrombotic F5 Leiden variant (rs6025) had no effect on warfarin dose requirement in our study $(P=0.4925)$.

\section{Multiple modelling}

To explore the potential of a warfarin dose prediction model, we combined the genes with the largest impact on warfarin dose (VKORC1, CYP2C9 and PROC) with patient characteristics (age, bodyweight, interaction with other drugs and indication for treatment) in a multiple regression model. This model explained $62 \%$ of the variance in dose. We then considered all nominally associated genes, VKORC1, CYP2C9, CYP2C19, CYP2C18, PROC, APOE, EPHX1, CALU, GGCX and $O R M 1-2$ in a model, which explained $76 \%$ of the 
Table 4 Multiple regression model that explains $73 \%$ of the variance in warfarin dose

\begin{tabular}{llll}
\hline Predictor & SNP & $P$-Value & $\begin{array}{l}\text { Univariate } \\
R^{2}\end{array}$ \\
\hline VKORC1 & rs9923231 & $<0.0001$ & 0.317 \\
CYP2C9 & rs1799853 $(* 2)+$ & $<0.0001$ & 0.159 \\
& rs1057910 $(* 3)$ & & \\
Age & & 0.0029 & 0.092 \\
PROC & rs2069919 & 0.0416 & 0.090 \\
Bodyweight & & 0.0075 & 0.057 \\
EPHX1 & rs4653436 & 0.1016 & 0.048 \\
Interaction & & 0.0878 & 0.036 \\
GGCX & rs12714145 & 0.0260 & 0.034 \\
ORM1 & rs1687390 & 0.0571 & 0.026
\end{tabular}

Univariate $R^{2}$-values are included for comparison

interindividual variance in warfarin dose. Variables with individual $P$-values above 0.2 and a low-explanatory value $\left(R^{2}\right)$ were subsequently removed from the model in a stepwise manner. We finally reached a model containing VKORC1, CYP2C $9 * 2$ and $* 3$, PROC, EPHX1, GGCX, ORM1-2, age, bodyweight and drug interactions which explained $73 \%$ of the variance in warfarin dose (Table 4). However, this speculative model requires validation in a large independent sample of warfarin patients.

\section{Conclusion}

VKORC1, CYP2C9, CYP2C19, CYP2C18, PROC and $A P O E$ were all significantly associated with warfarin dose after correction for multiple testing. Three linked $V K O R C 1 \mathrm{SNPs}$ and the $C Y P 2 C 9$ allele $* 3$ were the strongest genetic factors determining warfarin dose requirements. We fine mapped the VKORC1 and $C Y P 2 C$ regions in search of polymorphisms that might explain additional dose variance in our Swedish study population. However, none of the VKORC1 SNPs or haplotypes accounted for more dose variance than the three linked SNPs. Likewise, no CYP2C polymorphism contributed more to dose variance than $C Y P 2 C 9 * 2$ or *3. Apart from VKORC1 and CYP2C9, the most significant finding was the association of SNPs in PROC that reached gene-wise significance. Although factors II, VII and X have the strongest influence, it has been shown that protein $\mathrm{C}$, the product of the PROC gene, has an effect on one of the outcome parameters of the current study, i.e. the prothrombin time (Watala et al. 2003). If genetic variation in PROC influences the prothrombin time, which in turn determines the required warfarin dose, it is not improbable that genetic variation in PROC plays a role for warfarin dose. Furthermore, as previously reported, CYP2C9 extensive metabolisers who were homozygous for $A P O E^{*} E 4$ required higher warfarin doses than others (Kohnke et al. 2005b). Replication in a larger patient cohort will ascertain whether PROC and $A P O E$ are true determinants of warfarin dosing.

With this systematic warfarin study, we can explain $62 \%$ of the variance in warfarin dose in Swedish patients by using a multiple regression model of VKORC1, CYP $2 C 9 * 2 / * 3, P R O C$ and non-genetic factors. The addition of $E P H X 1, G G C X$ and $O R M 1-2$, to the model predicts an extra $\sim 10 \%$ of the variance. However, this model requires further validation in independent and larger samples, and will be tested in the WARG (http://www.druggene.org/) cohort of 1,500 Swedish warfarin treated patients. Even so, this future model will only be applicable for patients of European ancestry, and similar studies need to be performed in other ethnic groups. When all common alleles contributing to warfarin response have been identified in the major ethnic groups, a comprehensive dose model that is applicable regardless of ethnicity can be developed. Dosing models may subsequently be translated into clinical guidelines for warfarin prescription, and could have a major impact on the safety and efficacy of warfarin.

Acknowledgments The authors gratefully acknowledge Håkan Melhus and Qun-Ying Yue for initiating sample collection, Kristina Sörlin for extracting data from the medical records, Professor Munir Pirmohamed for helping to choose the candidate genes, David Vetrie for introduction to databases, Liz Sheridan for gene annotation, Ola Wallerman for technical assistance, and last but not least staff and participants of the study for their valuable contribution. This work was supported by the Wellcome Trust and the Swedish funding agencies: the Society of Medicine, Foundation for Strategic Research, Heart and Lung Foundation, and the Clinical Research Support (ALF) at Uppsala University. The sponsors had no role in the writing of this paper.

\section{References}

Aiach M, Nicaud V, Alhenc-Gelas M, Gandrille S, Arnaud E, Amiral J, Guize L, Fiessinger JN, Emmerich J (1999) Complex association of protein $\mathrm{C}$ gene promoter polymorphism with circulating protein $\mathrm{C}$ levels and thrombotic risk. Arterioscler Thromb Vasc Biol 19:1573-1576

Aquilante CL, Langaee TY, Lopez LM, Yarandi HN, Tromberg JS, Mohuczy D, Gaston KL, Waddell CD, Chirico MJ, Johnson JA (2006) Influence of coagulation factor, vitamin K epoxide reductase complex subunit 1 , and cytochrome $\mathrm{P} 450$ 2C9 gene polymorphisms on warfarin dose requirements. Clin Pharmacol Ther 79:291-302

Arbini AA, Bodkin D, Lopaciuk S, Bauer KA (1994) Molecular analysis of Polish patients with factor VII deficiency. Blood 84:2214-2220

Bell RG, Sadowski JA, Matschiner JT (1972) Mechanism of action of warfarin. Warfarin and metabolism of vitamin K 1 . Biochemistry 11:1959-1961 
Berkner KL (2000) The vitamin K-dependent carboxylase. J Nutr 130:1877-1880

Berkner KL, Runge KW (2004) The physiology of vitamin K nutriture and vitamin $\mathrm{K}$-dependent protein function in atherosclerosis. J Thromb Haemost 2:2118-2132

Bodin L, Verstuyft C, Tregouet DA, Robert A, Dubert L, FunckBrentano C, Jaillon P, Beaune P, Laurent-Puig P, Becquemont L, Loriot MA (2005) Cytochrome P450 2C9 (CYP2C9) and vitamin $\mathrm{K}$ epoxide reductase (VKORC1) genotypes as determinants of acenocoumarol sensitivity. Blood 106:135140

Cain D, Hutson SM, Wallin R (1997) Assembly of the warfarinsensitive vitamin $\mathrm{K}$ 2,3-epoxide reductase enzyme complex in the endoplasmic reticulum membrane. J Biol Chem 272:29068-29075

Chen LY, Eriksson N, Gwilliam R, Bentley D, Deloukas P, Wadelius M (2005) Gamma-glutamyl carboxylase (GGCX) microsatellite and warfarin dosing. Blood 106:3673-3674

Chen Y, Ferguson SS, Negishi M, Goldstein JA (2004) Induction of human CYP2C9 by rifampicin, hyperforin, and phenobarbital is mediated by the pregnane $\mathrm{X}$ receptor. J Pharmacol Exp Ther 308:495-501

Cheverud JM (2001) A simple correction for multiple comparisons in interval mapping genome scans. Heredity 87:52-58

Dahlbäck B (2005) Blood coagulation and its regulation by anticoagulant pathways: genetic pathogenesis of bleeding and thrombotic diseases. J Intern Med 257:209-223

Daly AK, King BP (2003) Pharmacogenetics of oral anticoagulants. Pharmacogenetics 13:247-252

D'Ambrosio RL, D'Andrea G, Cappucci F, Chetta M, Di Perna P, Brancaccio V, Grandone E, Margaglione M (2004) Polymorphisms in factor II and factor VII genes modulate oral anticoagulation with warfarin. Haematologica 89:1510-1516

D'Andrea G, D'Ambrosio RL, Di Perna P, Chetta M, Santacroce R, Brancaccio V, Grandone E, Margaglione M (2005) A polymorphism in the VKORC1 gene is associated with an interindividual variability in the dose-anticoagulant effect of warfarin. Blood 105:645-649

Dudbridge F (2003) Pedigree disequilibrium tests for multilocus haplotypes. Genet Epidemiol 25:115-121

Gabriel SB, Schaffner SF, Nguyen H, Moore JM, Roy J, Blumenstiel B, Higgins J, DeFelice M, Lochner A, Faggart M, Liu-Cordero SN, Rotimi C, Adeyemo A, Cooper R, Ward R, Lander ES, Daly MJ, Altshuler D (2002) The structure of haplotype blocks in the human genome. Science 296:22252229

Geick A, Eichelbaum M, Burk O (2001) Nuclear receptor response elements mediate induction of intestinal MDR1 by rifampin. J Biol Chem 276:14581-14587

Geisen C, Watzka M, Sittinger K, Steffens M, Daugela L, Seifried E, Muller CR, Wienker TF, Oldenburg J (2005) VKORC1 haplotypes and their impact on the inter-individual and inter-ethnical variability of oral anticoagulation. Thromb Haemost 94:773-779

Haining RL, Hunter AP, Veronese ME, Trager WF, Rettie AE (1996) Allelic variants of human cytochrome P450 2C9: baculovirus-mediated expression, purification, structural characterization, substrate stereoselectivity, and prochiral selectivity of the wild-type and I359L mutant forms. Arch Biochem Biophys 333:447-458

Huang W, Lin YS, McConn DJ II, Calamia JC, Totah RA, Isoherranen N, Glodowski M, Thummel KE (2004) Evidence of significant contribution from CYP3A5 to hepatic drug metabolism. Drug Metab Dispos 32:1434-1445

Kaminsky L, Zhang Z (1997) Human P450 metabolism of warfarin. Pharmacol Ther 73:67-74
Kohlmeier M, Salomon A, Saupe J, Shearer MJ (1996) Transport of vitamin K to bone in humans. J Nutr 126:1192S-1196S

Kohnke H, Scordo MG, Pengo V, Padrini R, Wadelius M (2005a) Apolipoprotein E (APOE) and warfarin dosing in an Italian population. Eur J Clin Pharmacol 61:781-783

Kohnke H, Sörlin K, Granath G, Wadelius M (2005b) Warfarin dose related to apolipoprotein E (APOE) genotype. Eur J Clin Pharmacol 61:381-388

Kristensen SR (2002) Warfarin treatment of a patient with coagulation factor IX propeptide mutation causing warfarin hypersensitivity. Blood 100:2676-2677

Landefeld C, Beyth R (1993) Anticoagulant-related bleeding: clinical epidemiology, prediction and prevention. Am J Med 95:315-328

Larsen TB, Lassen JF, Dahler-Eriksen BS, Petersen PH, Brandslund I (1998) Effect of anticoagulant therapy on the hypercoagulable state in patients carrying the factor V Arg506Gln mutation. Thromb Res 92:157-162

Lee SC, Ng SS, Oldenburg J, Chong PY, Rost S, Guo JY, Yap HL, Rankin SC, Khor HB, Yeo TC, Ng KS, Soong R, Goh $\mathrm{BC}$ (2006) Interethnic variability of warfarin maintenance requirement is explained by VKORC1 genotype in an Asian population. Clin Pharmacol Ther 79:197-205

Lehmann JM, McKee DD, Watson MA, Willson TM, Moore JT, Kliewer SA (1998) The human orphan nuclear receptor PXR is activated by compounds that regulate CYP3A4 gene expression and cause drug interactions. J Clin Invest 102:1016-1023

Li H (2001) A permutation procedure for the haplotype method for identification of disease-predisposing variants. Ann Hum Genet 65:189-196

Li T, Chang CY, Jin DY, Lin PJ, Khvorova A, Stafford DW (2004) Identification of the gene for vitamin $\mathrm{K}$ epoxide reductase. Nature 427:541-544

Loebstein R, Vecsler M, Kurnik D, Austerweil N, Gak E, Halkin $\mathrm{H}$, Almog S (2005) Common genetic variants of microsomal epoxide hydrolase affect warfarin dose requirements beyond the effect of cytochrome P450 2C9. Clin Pharmacol Ther 77:365-372

Loebstein R, Yonath H, Peleg D, Almog S, Rotenberg M, Lubetsky A, et al (2001) Interindividual variability in sensitivity to warfarin- Nature or nurture? Clin Pharmacol Ther 70:159-164

McGinnis R, Wadelius M, Chen LY, Eriksson N, Deloukas P (2006) Search for additional genetic determinants of warfarin dose. In: European Mathematical Genetics Meeting (abstract 20) Cardiff, Wales, 6-7 April

Morisseau C, Hammock BD (2005) Epoxide hydrolases: mechanisms, inhibitor designs, and biological roles. Annu Rev Pharmacol Toxicol 45:311-333

Nyholt DR (2004) A simple correction for multiple testing for single-nucleotide polymorphisms in linkage disequilibrium with each other. Am J Hum Genet 74:765-769

Otagiri M, Maruyama T, Imai T, Suenaga A, Imamura Y (1987) A comparative study of the interaction of warfarin with human alpha 1-acid glycoprotein and human albumin. J Pharm Pharmacol 39:416-420

Palareti G, Legnani C (1996) Warfarin withdrawal. Pharmacokinetic-pharmacodynamic considerations. Clin Pharmacokinet 30:300-313

Pritchard JK, Przeworski M (2001) Linkage disequilibrium in humans: models and data. Am J Hum Genet 69:1-14

Rettie AE, Korzekwa KR, Kunze KL, Lawrence RF, Eddy AC, Aoyama T, Gelboin HV, Gonzalez FJ, Trager WF (1992) Hydroxylation of warfarin by human cDNA-expressed cytochrome P-450: a role for P-4502C9 in the etiology of (S)-warfarin-drug interactions. Chem Res Toxicol 5:54-59 
Rettie AE, Wienkers LC, Gonzalez FJ, Trager WF, Korzekwa KR (1994) Impaired (S)-warfarin metabolism catalysed by the R144C allelic variant of CYP2C9. Pharmacogenetics 4:39-42

Rieder MJ, Reiner AP, Gage BF, Nickerson DA, Eby CS, McLeod HL, Blough DK, Thummel KE, Veenstra DL, Rettie AE (2005) Effect of VKORC1 haplotypes on transcriptional regulation and warfarin dose. N Engl J Med 352:2285-2293

Rost S, Fregin A, Ivaskevicius V, Conzelmann E, Hortnagel K, Pelz HJ, Lappegard K, Seifried E, Scharrer I, Tuddenham EG, Muller CR, Strom TM, Oldenburg J (2004) Mutations in VKORC1 cause warfarin resistance and multiple coagulation factor deficiency type 2. Nature 427:537-541

Sanderson S, Emery J, Higgins J (2005) CYP2C9 gene variants, drug dose, and bleeding risk in warfarin-treated patients: a HuGEnet systematic review and meta-analysis. Genet Med 7:97-104

Saupe J, Shearer MJ, Kohlmeier M (1993) Phylloquinone transport and its influence on gamma-carboxyglutamate residues of osteocalcin in patients on maintenance hemodialysis. Am J Clin Nutr 58:204-208

Sconce EA, Khan TI, Wynne HA, Avery P, Monkhouse L, King BP, Wood P, Kesteven P, Daly AK, Kamali F (2005) The impact of CYP2C9 and VKORC1 genetic polymorphism and patient characteristics upon warfarin dose requirements: proposal for a new dosing regimen. Blood 106:2329-2333

Scordo MG, Pengo V, Spina E, Dahl ML, Gusella M, Padrini R (2002) Influence of CYP2C9 and CYP2C19 genetic polymorphisms on warfarin maintenance dose and metabolic clearance. Clin Pharmacol Ther 72:702-710

Shikata E, Ieiri I, Ishiguro S, Aono H, Inoue K, Koide T, Ohgi S, Otsubo K (2004) Association of pharmacokinetic (CYP2C9) and pharmacodynamic (factors II, VII, IX, and X; proteins S and $\mathrm{C}$; and gamma-glutamyl carboxylase) gene variants with warfarin sensitivity. Blood 103:2630-2635

Spek CA, Koster T, Rosendaal FR, Bertina RM, Reitsma PH (1995) Genotypic variation in the promoter region of the protein $\mathrm{C}$ gene is associated with plasma protein $\mathrm{C}$ levels and thrombotic risk. Arterioscler Thromb vasc Bol 15:214-218

Sussman N, Waltershied M, Butler T, Cali J, Riss T, Kelly J (2002) The predictice nature of high throughput toxicity screening using a human hepatocyte cell line. Cell Notes 3:7-10

Takahashi H, Echizen H (2003) Pharmacogenetics of CYP2C9 and interindividual variability in anticoagulant response to warfarin. Pharmacogenomics J 3:202-214

Takahashi H, Kashima T, Nomizo Y, Muramoto N, Shimizu T, Nasu K, Kubota T, Kimura S, Echizen H (1998) Metabolism of warfarin enantiomers in Japanese patients with heart disease having different CYP2C9 and CYP2C19 genotypes. Clin Pharmacol Ther 63:519-528

Takahashi H, Wilkinson GR, Nutescu EA, Morita T, Ritchie MD, Scordo MG, Pengo V, Barban M, Padrini R, Ieiri I, Otsubo K, Kashima T, Kimura S, Kijima S, Echizen H (2006) Different contributions of polymorphisms in VKORC1 and CYP2C9 to intra- and inter-population differences in maintenance dose of warfarin in Japanese, Caucasians and AfricanAmericans. Pharmacogenet Genomics 16:101-110

van der Heijden JF, Rekke B, Hutten BA, van der Meer FJ, Remkes MG, Vermeulen M, Buller HR, Reitsma PH (2004) Non-fatal major bleeding during treatment with vitamin $\mathrm{K}$ antagonists: influence of soluble thrombomodulin and mutations in the propeptide of coagulation factor IX. J Thromb Haemost 2:1104-1109

Vecsler M, Loebstein R, Almog S, Kurnik D, Goldman B, Halkin H, Gak E (2006) Combined genetic profiles of components and regulators of the vitamin K-dependent gamma-carboxylation system affect individual sensitivity to warfarin. Thromb Haemost 95:205-211

Veenstra DL, You JH, Rieder MJ, Farin FM, Wilkerson HW, Blough DK, Cheng G, Rettie AE (2005) Association of Vitamin $\mathrm{K}$ epoxide reductase complex 1 (VKORC1) variants with warfarin dose in a Hong Kong Chinese patient population. Pharmacogenet Genomics 15:687-691

Visser LE, Trienekens PH, De Smet PA, Vulto AG, Hofman A, van Duijn CM, Stricker BH (2005) Patients with an ApoE epsilon4 allele require lower doses of coumarin anticoagulants. Pharmacogenet Genomics 15:69-74

Wadelius M, Pirmohamed M (2006) Pharmacogenetics of warfarin: current status and future challenges. Pharmacogenomics. $\mathrm{J}$ (in press)

Wadelius M, Chen LY, Downes K, Ghori J, Hunt S, Eriksson N, Wallerman O, Melhus H, Wadelius C, Bentley D, Deloukas P (2005) Common VKORC1 and GGCX polymorphisms associated with warfarin dose. Pharmacogenomics J 5:262270

Wadelius M, Sörlin K, Wallerman O, Karlsson J, Yue QY, Magnusson PK, Wadelius C, Melhus H (2004) Warfarin sensitivity related to $\mathrm{CYP} 2 \mathrm{C} 9, \mathrm{CYP} 3 \mathrm{~A} 5, \mathrm{ABCB} 1$ (MDR1) and other factors. Pharmacogenomics J 4:40-48

Wajih N, Sane DC, Hutson SM, Wallin R (2004) The inhibitory effect of calumenin on the vitamin K-dependent gamma-carboxylation system. Characterization of the system in normal and warfarin-resistant rats. J Biol Chem 279:25276-25283

Wallin R, Hutson S (1982) Vitamin K-dependent carboxylation. Evidence that at least two microsomal dehydrogenases reduce vitamin $\mathrm{K} 1$ to support carboxylation. J Biol Chem 257:1583-1586

Wallin R, Hutson SM, Cain D, Sweatt A, Sane DC (2001) A molecular mechanism for genetic warfarin resistance in the rat. Faseb J 15:2542-2544

Watala C, Golanski J, Kardas P (2003) Multivariate relationships between international normalized ratio and vitamin $\mathrm{K}$-dependent coagulation-derived parameters in normal healthy donors and oral anticoagulant therapy patients. Thromb J 1:7

Whittaker P, Bumpstead S, Downes K, Ghori J, Deloukas P (2006) Single Nucleotide Polymorphism analysis by matrixassisted laser desorption/ionization time-of-flight mass spectrometry. In: Celis J (ed) Cell biology: a laboratory handbook, 3rd edn. Elsevier, Amsterdam

Wu SM, Stafford DW, Frazier LD, Fu YY, High KA, Chu K, Sanchez-Vega B, Solera J (1997) Genomic sequence and transcription start site for the human gamma-glutamyl carboxylase. Blood 89:4058-4062

Yuan HY, Chen JJ, Lee MT, Wung JC, Chen YF, Charng MJ, Lu MJ, Hung CR, Wei CY, Chen CH, Wu JY, Chen YT (2005) A novel functional VKORC1 promoter polymorphism is associated with inter-individual and inter-ethnic differences in warfarin sensitivity. Hum Mol Genet 14:1745-1751

Zhang Z, Fasco MJ, Huang Z, Guengerich FP, Kaminsky LS (1995) Human cytochromes P4501A1 and P4501A2: R-warfarin metabolism as a probe. Drug Metab Dispos 23:1339-1346 